\author{
Tamiliia DOTSEVYCH ${ }^{1}$ \\ Tamara TKACH ${ }^{2}$ \\ Viktoriia SLABOUZ ${ }^{3}$
}

\title{
PHENOMENON OF “COMMUNICATIVE ACT": A PSYCHOLINGUISTICS PERSPECTIVE
}

The article presents the theoretical study of the phenomenon "communicative act" from the point of view of psycholinguistics. The article describes different approaches to the phenomenon "communicative act" and provides a representative and analysis of the main structural components. The article proves the text to be the basic unit of communication, determines the universal characteristics of the text as the basic manifestation of the communicative act (there are 11). The purpose of the article is to present the communicative act theoretically in an optimally wide range of problems that are relevant to modern science in general, and psycholinguistics in particular, and also to represent the theoretical analysis of the universal characteristics of the text as a basic manifestation of the communicative act. In addition, the article presents the data from a psycholinguistics proper perspective and also incorporates perspectives from psychology, philosophy, and philology that are necessary from the point of view of the essence of the problem. It is determined that a speaking person acts as a subject of communication, appearing at each moment of his/her communication simultaneously in three parts, as a set of "personality" phenomena - as a personality 1) language, 2) speech, and 3) communicative. It is shown that communication can be structuralized. The basic unit of communication is a communicative act, understood as a functionally integral piece of communication, the core of which is a text (a monologue, a dialogue or a polylogue). In each communicative act, four components are distinguished and, therefore, four aspects 1) the extra-linguistic aspect; 2) the semantic aspect; 3) the cognitive aspect; 4) the proper linguistic aspect.

Keywords: communication; communicative act; discourse; text; personality; psycholinguistics; psycholinguistic characteristics; psycholinguistic researches; universal characteristics of text.

1 Tamiliia Dotsevych, Dr in Psychology, Prof., Department of Psychology, Hryhorii Skovoroda University, 30, Sukhomlynskyi Str., Pereiaslav-Khmelnytskyi, Kyiv Reg., Ukraine, 08401; e-mail: tamiliia.dotsevych@gmail.com. ORCID: 0000-0001-6424-7801.

2 Tamara Tkach, Dr in Psychology, Prof., Department of Psychology and Pedagogy of Preschool Education, Hryhorii Skovoroda University, 30, Sukhomlynskyi Str., Pereiaslav-Khmelnytskyi, Kyiv Reg., Ukraine, 08401; e-mail: tkachtam@gmail.com (corresponding author). ORCID: 0000$-0001-5290-5395$.

3 Viktoriia Slabouz, Candidate of Philological Sciences, Associate Prof., Department of Foreign Languages, Donbas State Pedagogical University19, Henerala Batyuka Str., Sloviansk, Donetsk Reg., Ukraine, 84116; e-mail: queen_viktoriya28@ukr.net. ORCID: 0000-0003-1810-4054. 


\section{INTRODUCTION}

Having crossed the half-century frontier, psycholinguistics is confidently moving from a multidisciplinary science, born as a result of a combination of the object of linguistics and the subject of psychology, to an independent scientific branch of knowledge with a clearly defined methodology of psycholinguistic research, in particular, with developed and applied psycholinguistic toolset. Accordingly, there are more and more publications on the problems of psycholinguistics, there is a distribution of the latter to solve many individual and social problems. At the present stage, psycholinguistics exists as an independent discipline, whose premises can be found in the history of science. The origins of psycholinguistics are in the writings of famous linguists, psychologists, physiologists: W. von Humboldt, W. Wundt, A.A. Potebnia, I.A. Boduen de Kurtene, A.A. Shakhmatov, L.S. Vygotskii, I.M. Sechenov, S.I. Bershtein, A.N. Leontev, A.R. Luriia, N.I. Zhinkin etc. Most studies on the history of the development of psycholinguistics dwell on the determination of three main stages of its development, of which the first is associated with the name of Ch. Osgood and is called assocyanist, the second is named after N. Chomsky, and is known as transformational, the third - with the names of modern scholars (V.P. Belianin, O.O. Zalevskaia, D. Carroll, A.A. Leontev, J. Ferguson, R.M. Frumkina, T. Harley etc.), and is called the modern one (Zasiekina, Zasiekin, 2008). The main difference of the latter is the transition from the sentence to the complete text/discourse, i.e. to communication. Significance takes on the context and within the limits of psycholinguistics the meaning of the word because it is constructed in accordance with the specific situation of the subject's life or academic experience.

Psycholinguistics studies the processes of production and understanding of the text, the social, communicative conditions for the course of these processes, taking into account extralinguistic factors and the psychological significance of the language tools used. Moreover, the text as a phenomenon of linguistic and extralinguistic reality is a complex phenomenon that performs various functions: it is a means of communication, a way of storing and transmitting information, and a reflection of the individual's mental life, and a product of a certain historical era, and a form of cultural existence, and a reflection of certain sociocultural traditions. That is why there is such a variety of definitions of the text, such a variety of approaches to it. The construction of a psycholinguistic model of text perception should be based both on the basis of taking into account the substantial and formal characteristics of the text, as well as the psychological patterns of text perception by various recipients.

The issues about the psychological patterns in language, about the unconsciousness in language, about the correlation of consciousness and unconsciousness in connection with language and speech activity have been discussed by N.V. Krushevskii, F.F. Fortunatov, F. de Saussure, A.A. Potebnia, F. Boas, R. Jakobson etc.

Although scientists have had different attitudes to the relationship between language and psychology, they have been unanimous in that the distinction between psychology and linguistics is not good for both disciplines. In terms of methodology, this approach impoverishes linguo-psychology and undermines its foundations, and deprives linguistics of prospects and the humanitarian base. Thus, the definition of the place of communication in general and the communicative act in particular in the context of psycholinguistic research, analysis of the main directions of development of psycholinguistics in the new century, as well as the identification of the main directions of psycholinguistic research in 
the field of communication at the present stage of domestic and foreign thought is gaining timeliness (Kalmykov, 2018). The problem of understanding the text is one of the core problems under the conditions of modern information and communication society. It has been actively investigated by the scientists and scholars of different countries and areas of humanitarian science (Dijk, Kinch, 1998; Zalevskaia, 2015; Cummine, Cribben, Luu et al., 2016; Foucart, Romero-Rivas, Gort, Costa, 2016; Hubers, Snijders, Hoop, 2016; Bitan, Kaftory, Meiri-Leib et al., 2017; Bosco, Gabbatore, 2017; Sharon, Thompson-Schill, 2017; De Freitas, Peruzzi, Deacon, 2018; Hahne, Goldhammer, Kröhne, Naumann, 2018; Houghton, 2018; Murray, Starr, 2018 etc.).

The relevance of the study is due to the fact that the modern linguist cannot be familiar with psycholinguistics, at least with its foundations, and with the theory of communication as one of the main areas of psycholinguistic research, and is also predetermined by the need for a theoretical and practical study of psycholinguistic factors that influence on the origination and perception of the text in the process of communication, the study of specific and universal features of communication, characteristic of communication of representatives of different psycholinguistic historical-cultural communities.

The originality of the study is to consider theoretically the universal characteristics of the text as the main manifestation of a communicative act, the main focus is on structuring the basic unit of communication - the communicative act, as well as on the phenomena of a psycholinguistic nature that are behind the verbal form of speech and language behaviour and are included in the psycholinguistic plan of communication.

The purpose of the article is to present the communicative act theoretically in an optimally wide range of problems that are relevant to modern science in general, and psycholinguistics in particular, and also to represent the theoretical analysis of the universal characteristics of the text as a basic manifestation of the communicative act. At the same time, the article presents the data not only of psycholinguistics proper but also of psychology, philosophy, and philology, which seems necessary from the point of view of the essence of the problem under discussion. All of the above said determines the specific objectives of this article: 1) to give the reader an idea of the most significant and most interesting data which have had a huge impact on the development of psycholinguistics, have determined its current face and have reflected the main ideas of psycholinguistic research on the problem of communication; 2) to present the theoretical points of view of psycholinguists, psychologists, philologists on the problem of the communicative act; 3 ) to determine the universal characteristics of the text as a basic manifestation of the communicative act; 4) to represent the totality of "personality" phenomena (a speaking personality, a language personality, and a speech personality) and to clearly distinguish them.

\section{METHODS AND TECHNIQUES OF THE RESEARCH}

The following theoretical methods are used in the research: the analysis of scientific sources devoted to the problems of psychology, linguistics, psycholinguistics, the generalization of scientific investigations, the interpretation of communication laws, the separation of the baselines, the characterization of the discussions selected taking into account their intentional and purposeful orientation, conclusion, and the method of observation and introspection. 


\section{RESULTS AND DISCUSSIONS}

The emergence of psycholinguistics was due to the fact that there became recognized the necessity of developing a new scientific approach that could overcome the narrow departmental study of facts and thereby could provide new perspectives for their vision and explanation (Zalevskaia, 2013). The fact is that traditional linguistics and traditional psychology could not give a theoretical understanding and practical solution to a number of problems, such as, for example, language training (native and foreign), speech education of preschool children, speech impact, speech restoration after brain injuries, etc. In addition, according to scientists (Leontev, 1999; Frumkina, 1995; Zalevskaia, 2013), traditional sciences did not describe language as a psychic phenomenon. Psycholinguistics was designed to solve these and other problems.

The subject of psycholinguistics is extremely wide, in the focus of its attention today there are the following main areas: mechanisms for understanding, memorizing and producing speech; processes of generating and understanding speech; functioning language in the process of generating and perceiving speech; mechanisms for using language; mental dictionary; mastering the language (native, foreign); ontogenesis of children's speech, congenital language mechanisms, language environment of the child; the phenomenon of bilingualism; human speech mechanism and peculiarities of its formation and functioning; language (speech) disorders; intellectual processes in communication (Parret, 1993).

At the present stage of development, the following problems are the most relevant for Ukrainian and foreign psycholinguistics: non-verbal components of communication; correlation of the phenomena "language - man - society"; the phenomenon of the language personality; the image (picture) of the world; ethnocultural specifics of communication; intercultural communication, aspects of the language pictures of the world; theory and practice of translation (Krasnykh, 2001; Slama-Cazacu, 2007).

Psycholinguistics exists and develops in close genetic connection with psychology. At the same time, psychology is engaged in interpersonal communication, one of the main means of which is language (Leontev, 1999). Psycholinguistics is most closely associated with traditional linguistics, as it deals with a wide range of problems directly related to language. The origin and development of a new direction in psychology - cognitive psychology, which involves the study of the role of cognitive processes in speech activity, has led to the emergence and parallel development of cognitive linguistics, the aim of which is to study and describe the "conceptual sphere" (conceptosphere) of a person. Based on the language picture of the world, cognitive linguistics is engaged in studying the language consciousness, the language image of the world. The development of civilization, the emergence of new technologies has led to the fact that contacts with representatives of other cultures have begun to occupy an increasingly important place in human life. As a result, studies of interethnic, intercultural contacts, unfortunately, and conflicts are developing more and more actively. All the above mentioned has contributed to forming a new scientific direction in psycholinguistics - ethnopsycholinguistics. Psycholinguistics is also closely related to sociolinguistics, since, studying communication in the broad sense of this word, it cannot but consider the subject of communication - man and human society.

Man is a social being, social in nature, human in man is generated by his life in a society, in a culture created by man (Leontev, 1999). Consequently, human consciousness is a reflection of reality, refracted through the prism of socially developed language meanings, concepts, and individual human consciousness is possible only under the conditions of the 
existence of public consciousness. Many psychologists and psycholinguists use consciousness and language consciousness to describe one and the same phenomenon man, "To have consciousness is to own language. To own language is to own meanings. The meaning is a unit of consciousness (language, verbal meaning). Consciousness with this understanding is significant" (Leontev, 1994). By the definition of I.A. Zimniaia, "language consciousness is a form of existence of individual, cognitive consciousness of a homo sapiens, a speaking man, a communicating man, a man as a social being, as an individual" (Zimniaia, 1985). So, consciousness has a language nature, manifests itself in language, and language is the best reflection of human thought. It follows from what has been said that language consciousness is one of the aspects of human consciousness, that area of consciousness that is associated with the speech activity of man.

The picture of the world and the language picture of the world are closely connected with consciousness and language consciousness. Modern psycholinguists believe that the concepts of "consciousness" and "picture of the world" (the image of the world, the model of the world) are close, if not synonymous. The picture of the world is recognized as a reflection of the world in the head of man. Moreover, the picture of the world is understood as a reflection in the human psyche of the subject surrounding reality, mediated by objective meanings and corresponding cognitive schemes and amenable to conscious reflection (Leontev, 1999), as a result of the past of the people to which we classify ourselves (Ufimtseva, 1993). The picture of the world necessarily bears a national cultural imprint. The language picture of the world is the world in the mirror of language - the secondary, ideal world in language expression, the totality of knowledge about the world, reflected in vocabulary, phraseology, grammar. Each natural language reflects a certain way of conceptualizing (perceiving and organizing) the world. The meanings that are expressed in language form a unified system of views, which is a kind of "collective philosophy", which all the speakers of the given language adhere to as mandatory. The language picture of the world is a kind of material form in which the picture of the world is fixed and realized.

For socialization, becoming a member of a society, a person, therefore, an individual needs to learn, appropriate the experience gained by the members of the given society, achieve spiritual and material culture, and learn to use them. In other words, in order to become a member of one or another national-linguistic-cultural society, it is necessary to appropriate the consciousness of this society. One of the main channels for obtaining information in the process of socialization of an individual is language, which, according to the idea of E. Sapir, is "a powerful factor in socialization, perhaps the most powerful of the existing ones" (Sapir, 1993). This position of language is due to the fact that in the system of language signs, the social being of people is modeled, and displayed. Language is a part of social memory, a set of meanings that make up the indicative basis of activity not only of speech one but also of the other one, for example, cognitive. In this regard, it is necessary to form various competencies of an individual: language, speech, communicative, as well as cultural competency (Kravchenko, 2017).

The phenomenon of a language personality is closely connected with the above said, the teaching of which has recently become increasingly popular among researchers. But so far there is no single interpretation accepted and recognized by all. The spread of its understanding is wide - from the subject, individual, author of the text, native speaker and even just an informant (passive or active) to the language picture of the world and knowledge of the world, knowledge of language and knowledge about language, up to language national identity, the mentality of the people (Krasnykh, 2001). 
Iu. N. Karaulov proposes a structure of linguistic personality, consisting of three levels: 1) verbal-semantic, 2) cognitive, 3) pragmatic (Karaulov, 1987).

The verbal-semantic level assumes normal knowledge of the natural language for the native speaker, and for the researcher - the traditional description of the formal means of expressing certain meanings.

The cognitive level, the units of which are notions, ideas, concepts, developing in each language individuality into a more or less ordered, more or less systematized "picture of the world", reflects the hierarchy of values. The cognitive level of the structure of the language personality and his/her analysis involves the expansion of meaning and the transition to knowledge, which means that it covers the intellectual sphere of the personality, giving the researcher a way through the language, through the processes of speaking and understanding to knowledge, consciousness, processes of cognition of man.

The pragmatic level includes goals, motives, interests, attitudes, and intentions. This level provides the analysis of a logical and conditional transition from assessments of his/her speech activity to the understanding of real activities in the world in the language personality (Karaulov, 1987).

Scientists have been studying the first verbal-semantic level for a long time, the last two levels have become the object of close attention of researchers in recent decades, which is associated with the development of psycholinguistics, the theory of acts, cognitology and cognitive linguistics.

In connection with the problem of the language personality, the question arises of the relationship between language and speech, which scientists have been pondering over since the times of F. de Saussure. Currently, it is considered by a number of researchers through the prism of the language personality, and the language personality is comprehended in the light of the indicated dichotomy. The logical conclusion of such studies has become the thesis of the presence of not only the phenomenon of language personality but also the phenomenon of speech personality. Moreover, "any language personality is a multilayered and multicomponent paradigm of speech personalities" (Klobukova, Mikhalkina, 2001). Otherwise, according to the words of Iu. E. Prokhorov (Prokhorov, 2007), if a language personality is a paradigm of speech personalities, then, on the contrary, a speech personality is a language personality in the paradigm of real communication. In A.A. Leontev's opinion, the language personality is correlated with language as an object, and the speech personality is correlated with language as an ability (Leontev, 1999).

The language personality and speech personality are paradigmatic phenomena, and if the language personality is the paradigm itself, then the speech personality is an element of such a paradigm. But, as it is known, the system manifests itself in functioning. In the presented case, functioning the system (paradigm) is language as a process. The last component corresponds not to the language and speech personality, but to the person participating in the communication at the given moment, that is, the "communicative" personality. Thus, the totality of "personality" phenomena is presented as follows: a) a speaking personality is a person, one of the types of whose activity is speech activity, covering both the process of generating speech and the process of perceiving speech works; b) a language personality is a person who manifests himself/herself in speech activity, having a certain set of knowledge and ideas; c) a speech personality is a person who realizes himself/herself in communication, expresses and implements one or another communication strategy and tactics, selects and uses one or another set of tools, both linguistic and 
extralinguistic; d) a communicative personality is a specific participant in a communicative act, actually acting in real communication.

However, it should be noted that such a distinction between personality phenomena is conditional. Each human, as a "speaking person" at each moment of his/her speech activity, acts simultaneously as a language personality and a communicative personality. The main channel of socialization of an individual, the appropriation of social means, the achievements of the development of previous generations, cultural information is communication, in which an individual is included since childhood. Discourse or communication is one of the parties of the interaction of people in the process of their activities. The basic unit of any discourse is considered the text.

Text as a phenomenon is a very multidimensional, diverse and multifaceted phenomenon. In this regard, there is no, and, perhaps, there cannot be a single understanding and definition of the text. In the framework of the scientific paradigm that has developed lately and which integral component is psycholinguistics, the text is considered primarily as a product of speech and thinking activity. However, at present, it is absolutely obvious, and few people reject the assertion that the text as such (or its part, fragment) can be expressed by non-verbal means. In many studies, the text is considered precisely as a "creolised" product, expressed both by verbal and non-verbal paralinguistic, visual, etc. means. Today, even the most "persistent" linguists and psychologists do not dismiss the fact that in the direct communication up to $80 \%$ of information is received by communicants through non-verbal channels, and agree that it is impossible to study speech without taking into account extralinguistic factors affecting it. In other words, to analyse speech behaviour, ignoring the general context of communicative behaviour, not taking into account the inclusion of speech activity in the general circle of other activities (and this is one of the postulates of psychology and psycholinguistics), not taking into account the situation in which communication is carried out, and factors affecting the processes of generation and perception of speech work, without considering the linguistic (linguocultural) consciousness of the communicants, today does not seem justified, expedient and correct. The "paradox of the text", its verbal-non-verbal nature, is explained by the fact that from the whole spectrum of means of expressing some meaning (understood in this case from the standpoint of psycholinguistics), the author selects not only verbal, but also non-verbal (paralinguistic) means (for example, facial expressions, gestures and so on; much has been written about this (for example, by E.A. Zemskaya, 2007, G.V. Kolshansky, 2013, and other researchers).

Speaking of a comprehensive psycholinguistic analysis of the text (as one of the possible approaches), it should be borne in mind that almost all non-verbal components of communication and even all "dumb replicas" can be verbalized. Metaphorically speaking, the text can be presented as a finished picture, a "snapshot" (a kind of "clean" example of this approach is the understanding of the text by I.R. Galperin and his followers: the text is considered as a prepared, finished product that has undergone some processing (Galperin, 2008). If we continue our metaphor, discourse is a process and what surrounds it. Thus, it can be said that the text is what happened when the "artist" (author/authors of the text) put aside a brush or pencil. It can be a drawing, an instant sketch or a complex canvas. But the work on the product is completed, and what has been shaped turns into a life of its own. Discourse is not only and not so much what comes out of the author's hands, but also all the sketches in the margins, and all the sketches, and drafts, and the process of work, and the workshop, and the artist (author) himself/herself. Of course, with the perception of the 
text (and the text lives at the moment of its generation and perception by the recipient/recipients), all the aspects that are relevant to the discourse, all the parameters of the latter, are fundamentally important. And this is understandable since the text is an integral "element" of discourse. We speak more clearly and categorically: for us, the text is the main unit of discourse.

Discourse and text are impossible outside the communication process (much has been spoken and written about it by linguists and psycholinguists); it has been emphasized and repeatedly said that the text is a unit of communication; however, we will make a reservation right away that for us communication is not only a process of direct communication: it can be "scattered", "distanced" in time and space). Communication is carried out with the aim of transmitting / receiving / exchanging information, with the goal of some definite impact on the recipient (which of these is primary, which is secondary is a separate issue, it is not important for our study). Communication is a process and, like any process, can be divided. The basic unit of communication, from our point of view, is the communicative act (CA). The components of the $\mathrm{CA}$ are the situation and discourse; the main unit of the latter is the text.

Some characteristics of the psycholinguistic analysis of the text have been distinguished in the course of observation and analysis. The purpose of such an analysis is to understand whether the communicants have succeeded in a joint (speech) activity. The text has the following typical characteristics:

1. the consituation, which, following E.A. Zemskaya (Zemskaya, 2007), is understood as the extralinguistic reality in which a communicative act takes place; here are included all the main changes in the situation that occur in the course of a specific communicative act and are important for the communication process;

2. the time or the time factor in some cases is of fundamental importance for the course of a communicative act and, accordingly, the analysis of the latter; pauses between the replicas of the communicants are especially relevant;

3. the sequence of communicants' replicas - replicas are not considered mechanically, but their semantics and functional loading should be taken into account: communicative statements spoken sequentially can represent one or several replicas (the number of replicas is determined by the functional-semantic loading and the "role" that these statements play, since the first statement, for example, can "close" the previous (micro) text, and the next, respectively, can "open" the next); the important (but far from the only) indicator, in this case, is pausing;

4. the specific subject is a communicant, an author generating a specific speech-cognitive and thinking product;

5. the stimulus to speech action and the intention of speech generation;

6. the verbal form of the product of speech-cognitive and thinking activity, i. e. it is the text itself in direct presentation; the presentation of the text is accompanied by certain comments, noting the main features of the use of language tools in this particular product;

7. the reaction to a specific speech action, i. e. there is a reaction - verbal or non-verbal - to this action or not;

8. the structure of the text (microtexts and macrotexts);

9. the logical and semantic structure of the text, logical-semantic blocks are identified, by which certain fragments of communication are meant; 
10. the concrete speech act as a minifragment of communication, the communicativepragmatic orientation of the speech act is determined, its illocutionary meaning (this parameter is associated with the intention and, indirectly, with the stimulus of the given speech action);

11. the connections between speech actions, connections between the speech actions of one communicant are revealed and shown (if the speech actions are "spaced" in time and space, if the words of one communicant are interrupted by the words of another one, if there is some logical sequence of speech actions of one communicant) and among the speech actions of different communicants (a chain of "connected" remarks during dialogue, for example).

So, the text is considered as the main unit of discourse. The text may have a simpler or more complex structure. The smallest "textual" unit is microtext, which is characterized, in particular, by one predication, one microtheme, one microconcept when generated. Microtexts can be combined into units of a more complex structure-macrotexts. Macrotexts can have a certain number of microtexts in their composition, and, as our observations show, can also be summarized in texts of a "higher" level. In this case, one can speak about macrotexts of the first level, the second level, etc. A peculiar "peak" of such a hierarchical pyramid of texts is the macrotext of the "highest" level or, if the communicants manage to create a single text in the process of communication, this macrotext can be called "global". A similar view is correlated with the understanding of the text in psycholinguistics, which considers the text as "a form of expression of the hierarchy of semantic formations of varying degrees of complexity and significance" (Shakhnarovich \& Apukhtin, 1981).

The suggested typical characteristics of the text from the linguistic point of view allow determining the psycholinguistic characteristics of the text:

a) the presence/absence of the communicants' unifying single motive for carrying out their activities;

b) the presence/absence of the communicants' unifying unitary setting towards the implementation of their joint activities;

c) the implementation of joint (including speech) activities by communicants;

d) the receiving of a single text as a result of the communicants' joint activities;

e) the communicants' response to changes in the consituation (and if so, how);

f) the communicants' active and adequate participation in the process of communication.

All the above said allows determining the psycholinguistic characteristics of the text which are as follows: 1) actualizing a common setting towards the implementation of joint speech activities in the absence of a single global motive and a macroconcept that implements it, unfolding in the macrotext; 2) in the macrotext, the macroconcept of one communicant unfolds, while the second communicant actively participates in communication and contributes to the generation of a single macrotext; 3) carrying out joint (speech) activities, the communicants demonstrate full mutual understanding, which is manifested at the verbal and non-verbal levels and demonstrates that the communicants belong not only to one ethnic group but also to one society (i.e., communicants possess not only one cognitive base but also a single collective cognitive space); 4) the communicants are on the same social level and are fairly familiar. In general, in the process of communication, the communicants manage to create a single macrotext.

Communication is a necessary and specific condition for human life in society. The basis of communication is a problem situation, and it (communication) begins with the fact 
that a person has a need for communication. G.G. Pocheptsov defines the communicative act as "the act of interaction between the sender and the recipient, which is based on the message", i. e. when committing any communicative act, communication participants also make a speech one (Pocheptsov, 1986). Communication in the psychological sense is always the process of solving a communicative problem. Since communication is two-way in nature, the perceptual task, which determines the process of speech perception, is also solved in the communication process.

As it is known, any process, one way or another, lends itself to segmentation. Communication is of no exception either, which allows drawing a certain distinction within itself. A communication act (CA) can be recognized as such a fragment of communication, a segment of communication.

The following clarification also seems necessary: the communicative act and the speech act are different phenomena. Without dwelling on the theory of speech acts (J.L. Austin, J.R. Searle, J. Barwise, J. Perry, N. Fotion, E.V. Paducheva, N.D. Arutiunova, E.E. Razlogova etc.) it should only be noted that modern linguistics, psychology and psycholinguistics consider first of all separate speech actions (the word "act" in the name of this theory is, in our opinion, is an English tracing-paper in which "act" means "action"). A speech act is understood as a certain communicative action, a structural unit of linguistic communication, a discretely allocated tact, a quantum of discourse. We mean a larger fragment of communication. The core of such a fragment is the text, which can be represented by a monologue, dialogue or polylogue. Thus, the theory of speech acts is applicable in this case in a rather limited form (only when considering separate speech actions that are included in the analysed text).

A communicative act is a real and at the same time conditional unit. The paradox is due to the fact that, on the one hand, communication, as a process, has the property of divisibility/segmentation, but on the other hand, the boundaries of such a unit are mobile, somewhat blurred and subjective. Each communicative act has two components: the situation and discourse, which are two sides of the same coin. A situation is a fragment of an objectively existing reality, of which a verbal act can also be a part. As for the discourse, in linguistics, psychology and later in psycholinguistics, the interpretation of this concept has changed along with a change in the general paradigm of knowledge of the above sciences, as well as due to a change in approaches to studying oral and written communication and its results in various schools and directions representing this paradigm.

Thus, it can be assumed that the communicative act appears to be a broader concept regarding speech. So, for example, T.A. Van Dijk, revealing the essence of the term of a communicative act, also correlates it with a speech act, arguing that a speech act is a unit of transmitting information, when, as a communicative act, is a unit of communication. He also defines the units of the communicative act as follows: a speech act, an auditing act (a listener's act), and a situation of communication (Van Dijk, 2015).

According to the concept of A.E. Kibrik, the following components of a communicative act are distinguished: 1) discourse - "a communicative situation, including the consciousness of communicants and the text created in the process of communication"; 2) speech act - "discretely distinguished tact of discourse", in turn, the main elements of which are the speaker, the addressee, and the text; 3 ) a fragment of reality "introduced into consideration in this discourse: the external situation, which is the topic of communication", the communicative situation; 4) the communicative environment - "the consituation that makes up the subject environment of communicants (in time and space) in the process of 
communicative interaction" (Kibrik, 1992). Studying the structure of the communicative act, Kibrik pushed off from the direction of the text formation, that is why, in his conception, one can trace the tendency of functioning the language depending on the context of its use, while extralinguistic factors come to the fore here. But his concept emphasizes the act of the speaker, which makes it difficult to understand the structure of language interaction, which includes not only the act of the speaker but also the act of the listener.

One of the most important factors that determine the adequacy of communication is the presence of a common knowledge fund of communicants, a community of iconic means and a certain community of social experience. The specifics of communication when using a specific national language consists of 1) the specifics of building a speech chain, which is carried out according to the grammatical rules of a given language, and 2) the specificity of images of consciousness that reflect objects of a particular national culture. And to achieve mutual understanding, it is necessary that the communicants possess a community of knowledge about the language used, a community of skills in verbal communication, and a community of knowledge about the world in the form of images of consciousness (Tarasov, 1996).

For adequate communication, the necessary condition is the presence of a common presupposition base among the communicants or, in other terms, a common apperception base. The presupposition is a general fund of knowledge, common experience, a common thesaurus, general preliminary information that communicants possess. The categories of presupposition are the personality of the communicant, his/her life experience, his/her social characteristics. Presupposition serves as a zone of intersection of the cognitive spaces of communicants and is updated in the process of communication.

On the basis of what is put at the forefront, which aspects of communication attract particular attention and are the subject of consideration, various types of communication are distinguished. So, if for the analysis the social or national affiliation of the communicants is not relevant, if we are only interested in the universal in communication, the focus is on interpersonal communication as such. A similar approach is typical, in particular, for psychological research. Thus, interpersonal communication is the communication of communicants outside their membership in a particular social medium, i.e. at pre-national, national or supra-national levels. And if for the analysis of communication, the social or national affiliation of the communicants is important, which largely determines the specifics of communication in a particular language, one has to talk about two main oppositions: 1) monosocial or inter-social communication and 2) monoethnic (monocultural) and interethnic (intercultural) communication.

Communication can be represented as communication of "social medium" of different nature - different national-linguo-cultural communities. At this level, monocultural and intercultural communication are distinguished. Monocultural communication is a communication of representatives of one national-linguo-cultural community, and intercultural communication is a communication of different national-linguo-cultural communities, native speakers of different mental-linguistic complexes with different national communicative bases.

In this regard, intercultural communication can be defined as the process of direct interaction of cultures. Moreover, the process of interaction takes place within the framework of completely incompatible or partially coinciding national stereotypes of thinking and behaviour, which significantly affects the mutual understanding of commu- 
nication participants. There is much in common between inter-social communication and intercultural communication, but there are significant differences between them.

The main, basic types of communication are intercultural and inter-social. However, each person does not exist by himself/herself, but in society, enters into various societies and functions in the field of one or another national-linguo-cultural community. As a result, these types of communication do not appear in a "pure" form, but are the result of some intersection and interaction, forming the following types of communication: 1) monosocial monocultural communication; 2) inter-social monocultural communication; 3) monosocial intercultural communication; 4) inter-social intercultural communication (Krasnykh, 2001).

Modern communicative models (Komlev, 1996) are characterized by the allocation of poles, which are represented by the consciousness of the speaker (at the "entrance") and the consciousness of the listener (at the "exit"). In these models, communication is seen as a triad: origination - speech - perception, each link of which is equally significant and important. At the center of this triad is speech, which is quite natural, since speech is an activity that is carried out through communication (Vygotskii, 1982; Leontev, 2000; Leontev, 1999).

A fragment of communication, discourse, is a communicative act. At the same time, it is important to clarify the ratio of the communicative and speech act. A speech act is considered a communicative action, a structural unit of language communication. The main core of a speech act is a text that can be presented in monologue, dialogue or polylogue. Each communicative act has two component parts: the situation and discourse, which are the two sides of the same phenomenon. A situation is a fragment of an objectively existing reality, a verbal act of which can also be a part. Discourse is a verbalized speech-cognitive activity, which includes not only linguistic proper but also extralinguistic components.

The last considered concept of the structure of a communicative act is the concept of V.V. Krasnykh. The communicative act here has two structural components: discourse and the situation (the external side of communication, a fragment of real reality). In total, four components and four aspects of each communicative act are distinguished: 1) the extralinguistic aspect, the consituation is the objectively existing extralinguistic situation of communication; the conditions of communication in the broad sense and its participants (i.e. who, what, where, when); 2) the semantic aspect; the context is implicitly or explicitly expressed meanings that are the part of the situation, they are circling in discourse and relevant to the given communicative act; 3 ) the cognitive aspect; the presupposition is interaction of individual cognitive spaces of communicants, including the communicants' ideas about the consituation; 4) the linguistic aspect proper; speech is a product of direct speech production which communicates produce (Krasnykh, 2001).

The structural component of a communicative act is the discourse, which is a verbalized speech-thinking activity, which is a combination of a process and a result and has both linguistic and extralinguistic (linguo-cognitive) plans. The first one is associated with the language, realizes itself in the used language means and manifests itself in the totality of the generated texts (discourse as a result). The second plan is associated with language consciousness, which determines the choice of language means, affects the origination and perception of texts, manifesting itself in the context and presupposition (discourse as a process) 
Many researchers positively answer the question of the existence of different types of discourse, on the one hand, delimiting national discourses, and on the other, within the framework of one national discourse, highlighting, for example, poetic, scientific, aesthetic, political, legal discourse, etc. What concerns the allocation of types (kinds) of discourse, it should be noted that they are not separate isolated types or kinds of discourse, but serve as some "modification" of the latter, which is adapted in a certain way to the sphere in which it functions.

From a linguistic point of view, discourse is a single organism, in which at the same time the most diverse aspects of not only language but also language thinking are realized, because "everywhere ... psychological categories hide behind grammatical and normal categories" (Vygotskii, 1982). The text, as the realization of discourse, is such a unity in which everything is interconnected.

Psycholinguistics studies the processes of production and understanding of the text, the social, communicative conditions for these processes taking into account extra-linguistic factors and the psychological significance of the language means used. The text as a phenomenon of linguistic and extra-linguistic reality is a complex phenomenon that performs various functions: it is a means of communication, a way of storing and transmitting information, and a reflection of the individual's mental life, and a product of a certain historical epoch, and a form of cultural existence, and a reflection of certain sociocultural traditions. This determines the variety of definitions of the text, the variety of approaches to it. The construction of a psycholinguistic model of text perception should be based on the content and formal characteristics of the text, as well as on the psychological patterns of text perception by various recipients.

Being a unit of discourse, i.e. a component of a communicative act, the text has the basic properties characteristic of a communicative act as such. On this basis, as already noted, there are the aspects that must be taken into account when studying the text. These are: 1) extralinguistic, 2) cognitive, 3) semantic, 4) linguistic aspects proper.

The text as a unit of communication has a special semantic structure, reflecting the content structure of the elements of meaning; a certain logical structure, expressed in the sequence and structure of the presentation of semantic elements in the process of expanding the text; a communicative unity, predetermined by the communicative purposefulness of the text. The text is a certain system of semantic units of varying degrees of complexity, completeness, and significance, may and may not have verbally expressed wording in the text, that is, it may be non-verbalized and verbalized.

The origination and perception of the text, as well as other units of communication, is a psycholinguistic phenomenon in which linguistic and extralinguistic factors interact.

\section{CONCLUSIONS}

A speaking person acts as a subject of communication, appearing at each moment of their speech activity simultaneously in three parts, as a set of "personality" phenomena - as a personality 1) linguistic, 2) speech and 3) communicative. A speaking person is defined as a person, one of the types of activity of whose is speech activity (covering both the origination and perception of speech works); a linguistic person is a personality who manifests himself/herself in speech activity, having a certain set of knowledge and ideas; a speech person is a person who realizes himself/herself in communication, selects and implements one or another communication strategy and tactics, selects and uses one or 
another repertoire of means (both linguistic and extralinguistic proper); a communicative person is a specific participant in a particular communicative act, actually acting in real communication.

As the study has shown, communication lends itself to structuralization. The basic unit of communication is a communicative act, understood as a functionally integral piece of communication, the core of which is a text (a monologue, a dialogue or a polylogue). Each communicative act has two structural components: a situation (understood as a fragment of an objectively existing reality, of which a verbal act can be a part) and a discourse (understood as a verbalized speech-cognitive activity, which appears as a combination of a process and a result, having its own linguistic and linguistic-cognitive plans). In each communicative act, four components are distinguished and, therefore, four aspects: 1) the extra-linguistic aspect is associated with consituation; 2) the semantic aspect is determined by the context, the latter is understood as implicitly or explicitly expressed meanings that actually exist, which are part of the situation, reflected in the discourse and relevant to the given communicative act; 3 ) the cognitive aspect is directly related to presupposition; 4) the proper linguistic aspect is determined by speech, that is, the product of direct speech production, by what communicants produce.

The text as the main unit of discourse is a verbal and symbolically recorded product of speech-thinking activity, which is a "reaction" to the situation and its indirect reflection, possessing substantial completeness and informational self-sufficiency, as well as thematic, structural and communicative unity, as something objectively existing, material, amenable to fixation with the help of extralinguistic means and the very fact of its existence, it changes the world around us, as a kind of special predicative unit. From the point of view of the formal-informative structure and isolation in the discourse, the text is a speech product that opens with the unit with which verbalization of the speech-thinking flow begins and ends with the last verbally expressed response to the stimulus (verbal or non-verbal). Being the "core" of the communicative act, the text is characterized by the same peculiarities as the communicative act, and when analyzing it, therefore, the same four aspects should be taken into account: extralinguistic, cognitive, semantic, and linguistic proper. Our studies and observations show that having a single motive, a single setting towards the implementation of joint activities, and while implementing such, communicants manage to "create" a single text. If there is no single motive, but there is a setting towards the implementation of joint activities, the text may turn out. However, if there is a unified motive, but there is no indicated setting and joint activity, the communicants do not generate a single text (whatever complex or simple structure of it may be). Thus, if one looks at this situation from the other side, one can conclude that if there is no single text as a result of the speech-thinking activity of the communication participants, then this absence is significant: the communicants have not had an orientation toward joint activity (a single motive to the implementation of this activity may also be absent) or the participants in the communication have not been able (due to any reason) to implement such.

As for the prospects for further study of the phenomenon of the communicative act, the following can be distinguished: further development and refinement of the model of a communicative act; development of a classification of communicative acts; creation of a "descriptive list" of the most relevant, model Ukrainian communication acts. 


\section{REFERENCES}

Bitan, T., Kaftory, A., Meiri-Leib, A., Eviatar, Z., Peleg, O. (2017). Phonological ambiguity modulates resolution of semantic ambiguity during reading: An fMRI study of Hebrew. "Neuropsychology" 31(7). DOI: 10.1016/j. bandl.2017.09.002.

Bosco, F.M., Gabbatore, I. (2017). Theory of mind in recognizing and recovering communicative failures. "Applied Psycholinguistics" 38(1). DOI: 10.1017/S0142716416000047.

Cummine, J., Cribben, I., Luu, C., Kim, E., Bakhtiari, R., Georgiou, G., Boliek, C.A. (2016). Understanding the role of speech production in reading: Evidence for a print-to-speech neural network using graphical analysis. "Neuropsychology" 30(4). https://doi.org/10.1037/ neu0000236.

De Freitas P.V., Peruzzi Ella Da Mota, M.M., Deacon, S.H. (2018). Morphological awareness, word reading, and reading comprehension in Portuguese. "Applied Psycholinguistics" 39(3). DOI: $10.1017 /$ S0142716417000479.

Foucart, A., Romero-Rivas, C., Gort, B. L., Costa, A. (2016). Discourse comprehension in L2: Making sense of what is not explicitly said. "Brain and Language" 163. DOI: 10.1016/j.band1.2016.09.001.

Frumkina, R.M. (1995). Est li u sovremennoi lingvistiki svoia epistemologiia [Whether Modern Linguistics Its Own Epistemology]. "Iazyk i nauka kontsa XX veka - Language and Science of the End of the $20^{\text {th }}$ Century”. Moscow: RGGU.

Galperin, I.R. (2008). Tekst kak obekt lingvisticheskogo issledovaniia [Text as an object of the linguistic]. Moskva.

Hahne, C., Goldhammer, F., Kröhne, U., Naumann, J. (2018). The role of reading skills in the evaluation of online information gathered from search engine environments. "Computers in Human Behavior" 78. DOI: 10.1016/j.chb.2017.10.004.

Houghton, G. (2018). Action and perception in literacy: A common-code for spelling and reading. "Psychological Review" 125(1). https://doi.org/10.1037/ rev0000084.

Hubers, F., Snijders, T., Hoop, H. (2016). How the brain processes violations of the grammatical norm: An fMRI study. "Brain and Language" 163. DOI: 10.1016/j.bandl.2016.08.006.

Kalmykov, G.V. (2018). Psihologo-profesijnij diskurs yak virazhennya intencionalnoï spryamovanosti subekta movlennya na adresata [Psychological-Professional Discourse as an Expression of the Intentional Orientation of the Subject of Speech to the Addressee]. "Psiholingvistika - Psycholinguistics" 23(1). DOI: 10.5281/zenodo.1212362.

Karaulov, Iu.N. (1987). Russkii iazyk $i$ iazykovaia lichnost [Russian Language and Language Personality]. Moscow: Nauka.

Kibrik, A.E. (1992). Ocherki po obshchim i prikladnym voprosam iazykoznaniia [Essays on General and Applied Issues of Linguistics]. Moscow.

Klobukova, L.P., Mikhalkina, I.V. (2001). Problemy obucheniia audirovaniiu v zerkale realnoi kommunikatcii [Problems of Teaching Listening Comprehension in the Morror of Real Communication]. "Mir russkogo slova - World of the Russian Word" 3.

Kolshansky, G.V. (2013). Obektivnaia kartina mira v poznanii i iazyke [Objective picture of the world in cognition and language]. Moskva: LIBROKOM.

Komlev, N.G. (2006). Komponenty soderzhatelnoi struktury slova [Components of the Content Structure of the Word]. Moscow: KomKniga.

Krasnykh, V.V. (2001). Osnovy psikholingvistiki i teorii kommunikatcii [Fundamentals of Psycholinguistics and Theory of Communication]. Moscow: ITDGK «GNOzis». 
Kravchenko, A.V. (2017). "Soznanie» kak ekologicheskoe poniatie ["Consciousness" as an ecological concept]. "Noosfernye issledovaniia - Noospheric Studies" 2(18).

Leontev, A.A. (1999). Osnovy psikholingvistiki [Fundamentals of Psycholinguistics]. Moscow. Leontev, A.N. (2000). Lektcii po obshchei psikhologii. Uchebnoe posobie [Lectures on General Psychology. Manual Guide]. Moscow: Smysl.

Leontev, A.N. (1994). Filosofiia psikhologii [Philosophy of Psychology]. A.A. Leonteva, D.A. Leonteva (Es.). Moscow: Izd-vo Mosk. un-ta.

Lotman, Iu.M. Vnutri mysliashchikh mirov: chelovek - tekst - semiosfera - istoriia [Inside Thinking Worlds: Man - Text-Semiosphere - History]. Moscow: Iazyki russkoi kultury.

Murray, S.E., Starr, W.B. (2018). Force and Conversational States [in:] Fogal, D., Harris, D., Moss, M. (Eds.), New Work on Speech Acts. New York: Oxford University Press.

Parret, H. (1993). The Aesthetics of Communication: Pragmatics and Beyond. Dordrecht.

Pocheptsov, G.G. (1986). Osnovy pragmaticheskogo opisaniia predlozheniia [Fundamentals of Pragmatic Description of Sentece]. Kiev: "Vishcha shkola".

Prokhorov, Iu.E., Sternin, I.A. (2007). Russkie: kommunikativnoe povedenie [The Russians: Communicative Behaviour]. Moscow: Nauka: Flinta.

Sapir, E. (1993). Izbrannye trudy po iazykoznaniiu i kulturologii [Collected Works on Linguistics and Culturology]. Moscow: Progress [in Russian].

Shakhnarovich, A.M., Apukhtin, V.B. (1981). Psikholingvisticheskie problemy predikatcii $i$ obuchenie ponimaniiu tekstov [Psycholinguistic problems of predication and teaching the text understanding]. "Aspekty izucheniia teksta. Sbor. nauch. Trudov - Aspects of Text Studying. Collection of Scientific Works". Moskva.

Sharon, E.M., Thompson-Schill, L. (2017). Tracking competition and cognitive control during language comprehension with multi-voxel pattern analysis. "Brain and Language" 165. DOI: 10.1016/j.band1.2016.11.002.

Slama-Cazacu, T. (2007). Psycholinguistics, Where to in the $21^{\text {st }}$ Century? Challenging Tasks for Psycholinguistics in the New Century. J. Arabski (Ed.). Katowice: University by Silesia.

Tarasov, E.F. (1996). Mezhkulturnoe obshchenie - novaia ontologiia analiza iazykovogo soznaniia [Intercultural Communication - New Ontology of Analysis of Language Consciousness]. Etnokulturnaia spetcifika iazykovogo soznaniia - Ethnocultural Specifics of Language Consciousness, (7-2). Moscow.

Ufimtseva, N.V. (1993). Chelovek i ego soznanie: problema formirovaniia [Man and His Consciousness]. "Iazyk $i$ soznanie: paradoksalnaia ratcionalnost - Language and Consciousness: Paradox Rationality”. Moscow.

Van Dijk, T.A., Kinch, V. (1988). Strategii ponimaniya svyaznogo teksta [Strategies for understanding of coherent text]. "Novoye $v$ zarubezhnoy lingvistike - The New in Foreign Linguistics" 23.

Van Dijk, T.A. (2015). Iazyk. Poznanie. Kommunikatciia [Language. Cognition. Communication]. (O. Gulyga, S. Romashko, M. Dmitrovskaia, Translators). Moscow: LENAND. Vygotskii, L.S. (1982). Myshlenie i rech [Thinking and Speech], Vol. 2. Moscow.

Zalevskaia, A.A. (2013). Vvedenie v psikholingvistiku: uchebnik [Introduction to Psycholinguistics: Textbook]. Moscow: Direkt-Media.

Zasiekina, L.V., Zasiekin, S.V. (2008). Psykholinhvistychna diahnostyka [Psycholinguistic Diagnostics]. Lutsk: RVV «Vezha» Volyn. nats. untu. 
Zemskaya, E.A. (2007). Slovoobrazovanie kak deiatelnost [Word formation as an action]. M.: Izd-vo KomKniga.

Zimniaia, I.A. (1985). Psikhologicheskie aspekty obucheniia govoreniiu na inostrannom iazyke [Psychological Aspects of Teaching Speaking a Foreign Language]. Moscow: Prosveshchenie.

DOI: $10.7862 /$ rz.2020.hss.27

The text was submitted to the editorial office: January 2020.

The text was accepted for publication: September 2020. 
